\title{
How does history of sport rank in sciences - A discussion of the paradigm of the history of sport
}

\author{
Piotr Godlewski
}

Gdansk University of Physical Education and Sport, Gdansk, Poland

\section{abstract}

No science can be a province of itself without its theories, neither can history of sport be. Hence a question arises of how it is possible for specific research programmes to have been pursued for more than half a century without their own theories and the paradigm [1], understood here as a collection of concepts and theories composing the methodological basis. What is more, a group of researchers with considerable achievements in historiography of sport, physical education and tourism have not produced anything that could be called a methodology. Retrospective insight into sport may take two forms: research into historic sport and research into history of sport. Research into historic sport is usually carried out by university history departments and is focused on issues in sport, while issues related to social processes, complex relationships between sport and politics, social and cultural processes are the objective of historical research. Presently arriving at interesting results in historical research is more likely where two or more disciplines meet - hence a sociologist knowledgeable in sport, cultural anthropologist, etc. Certainly, new subdisciplines will be emerging: historical psychology of sport and historical sociology of sport. The fact that mass sources are available makes research into recent history of sport turn into a multidisciplinary study area. An increase in the number of interdisciplinary, multidisciplinary and transdisciplinary links will evolve.

Key words: history of sport, history methodology, paradigm, physical culture.

\section{article details}

Article statistics: Word count: 4,458; Tables: 0; Figures: 8; References: 14

Received: June 2020; Accepted: August 2020; Published: November 2020

Full-text PDF: http://www.balticsportscience.com

Copyright ๑ Gdansk University of Physical Education and Sport, Poland

Indexation: Celdes, Clarivate Analytics Emerging Sources Citation Index (ESCI), CNKI Scholar (China National Knowledge Infrastructure), CNPIEC, De Gruyter - IBR (International Bibliography of Reviews of Scholarly Literature in the Humanities and Social Sciences), De Gruyter - IBZ (International Bibliography of Periodical Literature in the Humanities and Social Sciences), DOAJ, EBSCO - Central \& Eastern European Academic Source, EBSCO - SPORTDiscus, EBSCO Discovery Service, Google Scholar, Index Copernicus, J-Gate, Naviga (Softweco, Primo Central (ExLibris), ProQuest - Family Health, ProQuest - Health \& Medical Complete, ProQuest - Illustrata: Health Sciences, ProQuest - Nursing \& Allied Health Source, Summon (Serials Solutions/ProQuest, TDOne (TDNet), Ulrich's Periodicals Directory/ulrichsweb, WorldCat (OCLC)

Funding: This research received no specific grant from any funding agency in the public, commercial, or not-for-profit sectors.

Conflict of interests:

Corresponding author:

Open Access License: Author has declared that no competing interest exists.

Dr hab. P. Godlewski prof. AWFiS, Gdansk University pf Physical Education and Sport, Kazimierza Górskiego 1, 80 336 Gdansk, Poland; e-mail: piotr.godlewski@awf.gda.pl.

This is an open access article distributed under the terms of the Creative Commons Attribution-Non-Commercial-NoDerivatives 4.0 International (https://creativecommons.org/licenses/by-nc-nd/4.0/), which permits use, distribution and reproduction in any medium, provided the original work is properly cited, the use is non-commercial and is otherwise in compliance with the license. 


\section{INTRODUCTION}

No science can be a province of itself without its theories, and neither can the history of sport. If we intend to study the history of science, arts, theatre, film, music, literature, medicine, it will soon turn out that no progress is possible without a theoretical paradigm. Hence a question arises of how it is possible for specific research programmes to have been pursued for more than half a century without their own theories and the paradigm ${ }^{1}$, understood here as a collection of concepts and theories composing the methodological basis. Moreover, a group of researchers with considerable achievements in historiography of sport, physical education and tourism have not produced anything that could be called a methodology. Well, the case is probably more complex than it seems to be; however, at least two key causes can lie at the bottom. Firstly, part of the researchers who graduated from history departments may have concluded that history of sport was a history of a specific branch, and as such was subject to the paradigms of the history methodology. Secondly, there are those, including distinguished scholars in these areas, who avoid discussions on methodologies and steer of theoretical problems taking the pragmatic as a guideline. And the fact that both do not hang in the mid-air, represent various research centres and have their followers, most often disciples after their own model, makes them considerably numerous.

\section{SOCIAL AND HUMANISTIC ISSUES IN PHYSICAL CULTURE SCIENCES}

Humanistic and social studies of physical culture are most of all preoccupied with examining man in a web of social forces, and thus his personality (education, background, shaping a healthy lifestyle, forming a desired habit, rational use of leisure time). Therefore, if we want to identify ourselves with any broader definition of physical culture - it becomes obvious that any researcher on the past should entail the whole of sport, physical education, tourism, etc., in other words all the components - if not those of the Marxist dogma - then with the present deeply humanistic and broad concept of physical culture.

The major subject of physical culture sciences is man, while research concentrates on anthropological issues. Within the social and humanistic thematic groups in physical culture sciences of significance is research in the field of pedagogy, that is the theory of physical education and pedagogy of sport. Among social and humanistic thematic groups, which are simultaneously academic courses, sport psychology, philosophy of physical culture, sociology of physical culture, sport sociology, institutionalisation and management of physical culture as well as institutionalisation and management of tourism emerged ${ }^{2}$ (Fig. 1).

Sciences of physical culture entail the humanities and biological sciences which explore issues pertaining to this culture. H. Grabowski draws attention to the fact that initially humanists did not realise what their role in the sciences of physical culture was supposed to be. The period when dialectical materialism was at its fullest came to their assistance [however, the positive content of certain desiderata was neglected]. In time humanists started to liberate themselves from the strict discipline of the methodology of natural history. Finally, a doctrine prevailed that "the world of nature and the world of culture are like two sides of a coin, which although a unity, cannot be observed from the same

\footnotetext{
Paradigm - as understood by Thomas Kuhn - is a collection of concepts and theories forming the fundamentals of a given science. Theories and concepts forming a paradigm are usually not questioned, at least as long as the paradigm is creative cognitively - that is by means of it specific theories can be formulated, consistent with experienced (historical) data, which lay grounds for a given science. Simply speaking, a paradigm is understood as a paradigm of a scientific method, which validates an activity as a scientific activity.

It should be worth remembering that physical culture sciences striving to become autonomous sciences since the 1950 s have been following practical demand. Sometimes their executive agent, that is methodologies, were longer than the theory itself. Currently, the standards in force at the first and second tier of higher education require that obligatory courses should cover: anatomy, anthropology, anthropomotorics, biochemistry, physiology as regards biology courses, while courses in sociology and the humanities should cover: philosophy, health promoting education, history of physical culture, pedagogy, psychology, sociology, theory of sport and of physical education.
} 
perspective" [1: 93]. The snag was that the body in its biological perspective could not be described with the humanist language, while the body as a value defies a biological description; only human psychomotor activities could be subject to natural sciences and the humanities.

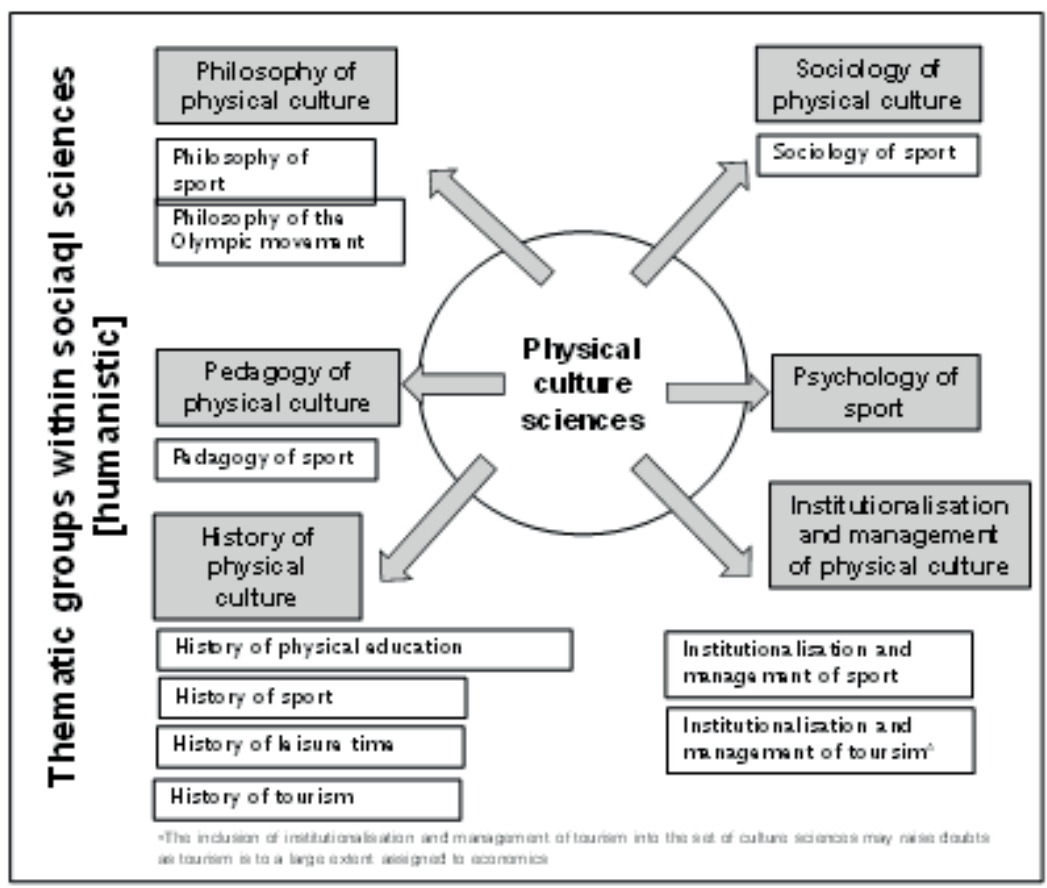

Fig. 1. Division of physical culture sciences into thematic groups within social and humanistic issues (author's own elaboration)

\section{RANKING OF HISTORY OF SPORT IN SCIENCES}

As science of physical culture became autonomous, attempts were made to consolidate it in layers [1: 103]. It has to be realised that humanists do not enjoy a privileged position among the researchers of physical culture. This is caused by dominant naturalists. They created and shaped sciences of physical culture. Originally, the majority of researchers focused on "man in his bodily dimension" [2: 26-27] ${ }^{1}$. A biologistic lean that science of physical culture stubbornly shows gave way to humanisation. Breakthrough dates are a 1954 scientific conference, a return to F. Znaniecki's thought, works by M. Demel, A. Pawłucki, Z. Krawczyk. How history of sport ranks in sciences cannot be easily assessed. A number of questions will immediately pop up: whether history of sport (of physical culture) is part of history of culture [history of education], or is it part of history of science, history of spiritual culture [literature, theatre, music, arts]? Is it at the same time part of material culture [agrarian culture, technical culture]? To what extent is history of sport connected with everyday history [daily routines, family life, and history of man outside workplace]? Certainly, for a sociologist historian, anthropologist of culture, a representative of psychohistory history of sport, sport policy will always mean different fields of study.

Research in sciences of physical culture comprises both fundamental and applied research. Research in history of sport, of physical education, of tourism and leisure, is placed within the group of fundamental research, which results in lesser interest by the practical. This implies also a lesser demand for detailed research and monographs.

\footnotetext{
${ }^{1}$ The physical aspect of physical culture is most likely dictated by the dominance of the muscle element. Physical control of the body means the control of the striate muscles where muscle work dominates - hence control of the physicality of humans is fully justified. If a movement is made, for instance in dance, run, jump or leap, the human nervous system will send relatively simple signals to the muscles, movement signals that are coordinated by analysers (a functional unit: a receptor, centripetal nerves, central nervous junction) in a feedback loop (control of the system by inputting the results of the previous task). This type of work differs from a complicated yet still little known mental effort, which is dictated by man's awareness via his brain. Man has a considerable control of his striate muscles, incomparably exceeding his control of the brain.
} 


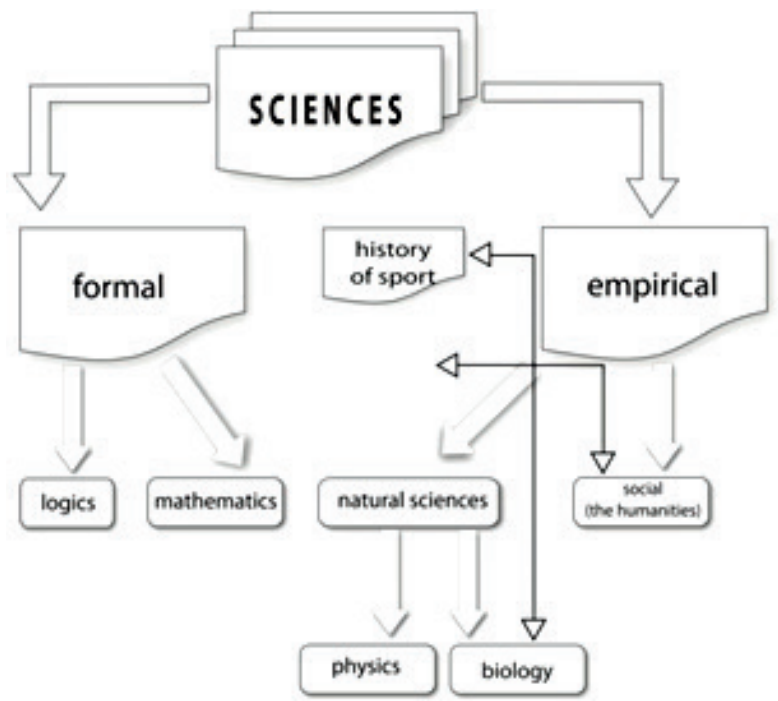

Fig. 2. The thematic group of history of sport, of physical education of tourism and leisure in the division into formal and empirical science

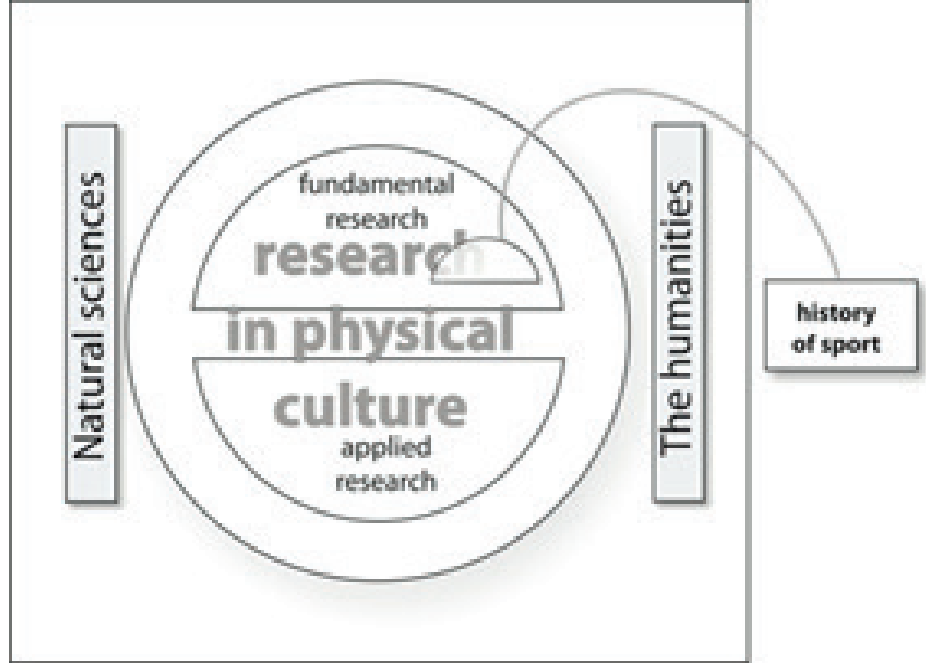

Fig. 3. Place of the thematic group of history of sport, of physical education, of tourism and leisure among natural sciences, the humanities, fundamental and applied research

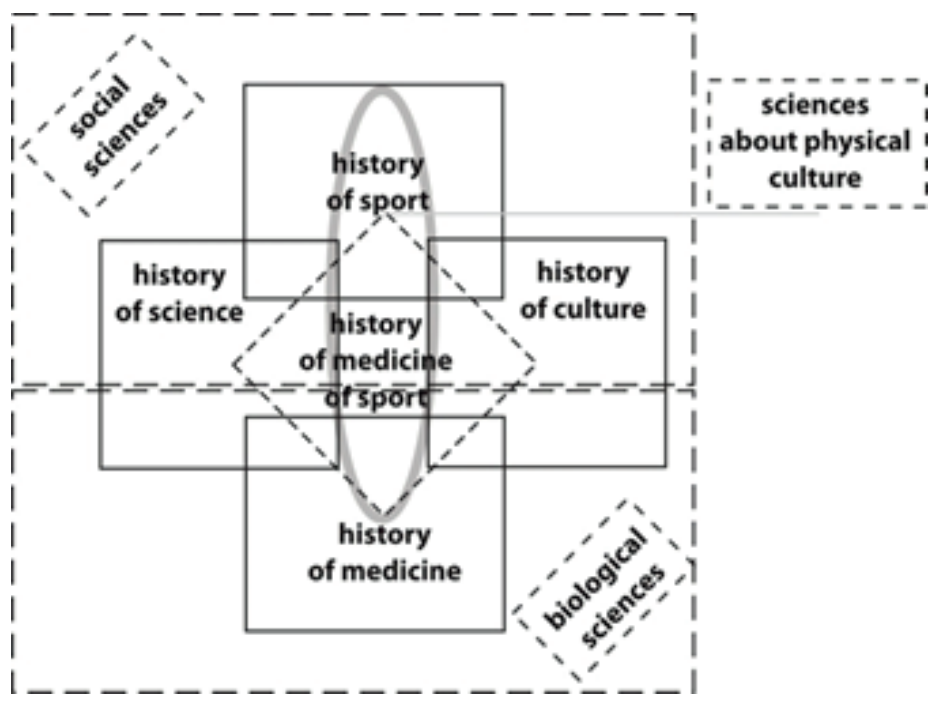

Fig. 4. History of sport among various areas of science 
The mutual permeation of areas of historical sciences and overlapping of different contemporary historical research open up wider perspectives for researchers into history of sport to research and arrive at more comprehensive and interesting results.
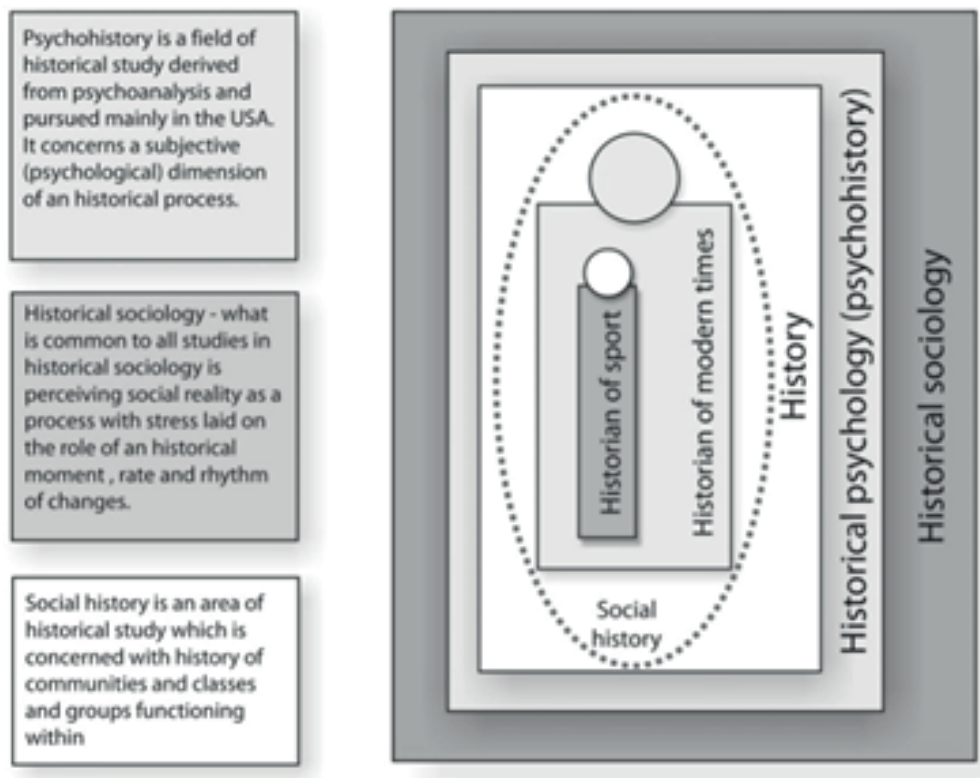

Fig. 5. The thematic group of history of sport, of physical education of tourism and leisure in the division into formal and empirical science

Possibly, microhistory studies might be an alternative solution. Yet, even here, dilemmas arise for what is achieved in microhistory remains useless as long as it is outside the broader frame of tendencies and developmental phenomena, while those researching in history of sport, of tourism and leisure, capable of producing outstanding studies are in short supply. Today it is difficult to say if there will emerge capable scholars ready to tackle such themes as the one by Robert Darton ${ }^{1}$. The method to pick up a subject theme seems to be simple. Once we have encountered what is hard to understand, what is of importance to a given culture or community - this will mean we have found something through which we would be able to capture an alien system of meanings, which, subsequently, will let us explain it.

The contemporary standards of science are generally known. Now, it can only be pretended that history of sport, of physical education, of tourism and leisure is something unknown in the scientific perspective, not what it is commonly felt to be. It is obvious that history of sport cannot be a subjective reconstruction of the past, but its objective documentation. In order to understand a certain history, it is not enough to conduct deep and reliable research, it is also interpretation, continuous advancing of theses and challenging them, looking for the truth from more than one perspective. Therefore, the sport historian's work should not be reconstruction or recreating what used to be.

\footnotetext{
${ }^{1}$ In Paris at the end of 30s in the 18th century a group of apprentice printers with bars, sticks and broomstick massacred to death cats living in the neighbourhood, killing the master printer's wife' furry tabby cat. This macabre scene, as it would have been called nowadays, was related as a good joke by Nicolas Contant in his diary. 250 years later this story was found by Robert Darton, the outstanding book historian, whose essay became one of the important links between two branches of science: history and anthropology. He chose this repugnant episode, a hideous joke by young apprentice printers for he could not...understand it.
} 


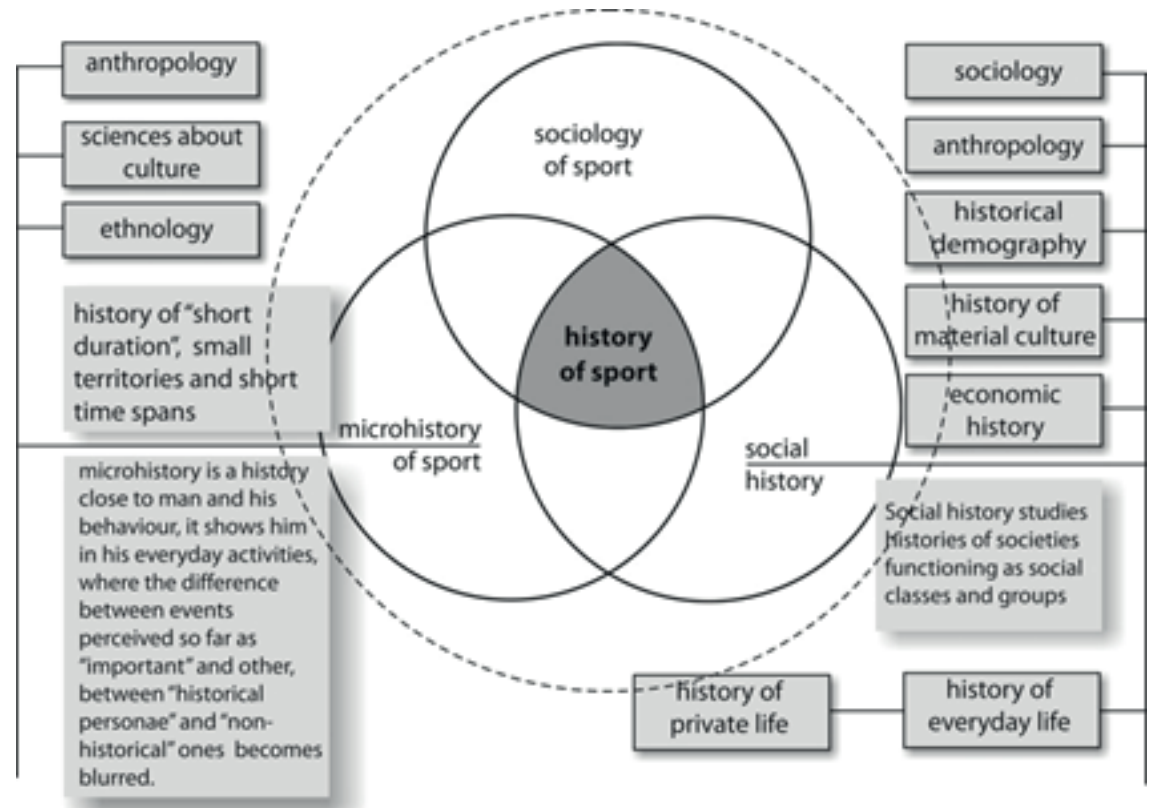

Fig. 4. History of sport among various areas of science

\section{DUALISM OF THE METHODOLOGICAL APPROACH}

Therefore, what is history of sport studied as a scientific activity within the scope of sciences of physical culture as taught at university schools of physical education? Everything suggests that such a history of sport has formally not much to do with history per se. As a concise thematic group, it gathers the majority of researchers around university schools of physical education and around sciences of physical culture. In the sphere of sport, it is a science of the evolution of functional abilities of man, of his activity outside the workplace, competition, rivalry, body improvement, of such activities in social life like entertainment, play, game and social interactions taking place between humans during all these processes.

A retrospective insight into sport may take two forms: research into historic sport and research into history of sport. Research into historic sport is usually conducted by university history departments and is focused on issues in sport, while issues related to social processes, complex relationships between sport and politics, social and cultural processes are the objective of historical research. On the other hand, research into history of sport is conducted chiefly by research centres at university schools of physical education, most often by experts in sciences of physical culture, and generally concentrates on chronicles of local history of a single or a couple of sport disciplines and description of their organisation, development from a national perspective in historical periods, and compiled biographies. In this way, research is enclosed in thematic enclaves, while essential problems from a perspective of sciences of physical education remain hibernated. The evil seems to be rooted at the very beginning - in the choice of subject matters and in methodologically oversimplified doctoral theses.

If we assume that those who write on history of sport, of physical education, of tourism and leisure in Poland are at two opposing poles, then we should be ready to face different, specific results. Thus, historians, whom we may generally refer to as university ones, and specialists in physical culture (from university schools of physical education and other non-university type of schools) will write about traditions of sport differently. A complex 
which manifests itself in pretending to be historians that a certain group of specialists in physical education have developed is difficult to understand. As if they were not to admit the fact that they are not ones. It is a horse of another colour if academics from University Schools of Physical Education and from departments offering courses in physical education have historical background, then they are at both ends. It is the research activities by that group which can bring most effective results in history of sport.

\section{Competences of a researcher in history of sport}

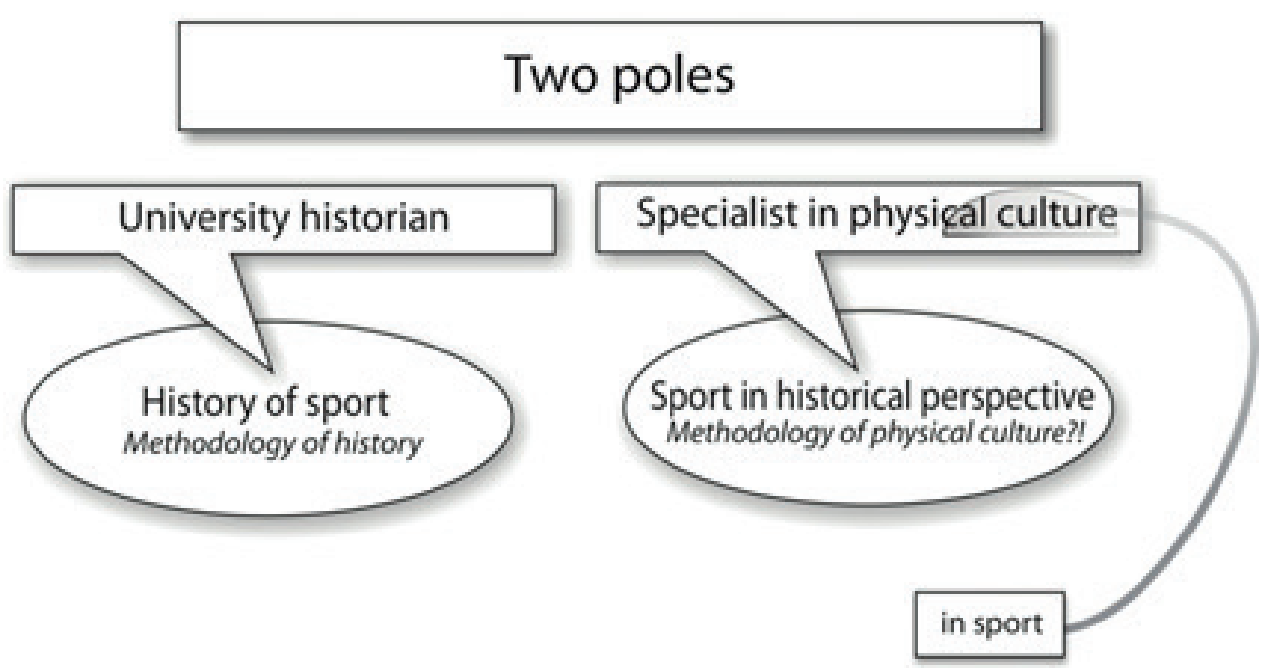

Fig. 7. A sport historian's competences contended

\section{DISCUSSION ON THE PARADIGM OF THE HISTORY OF SPORT}

Should we assume that the humanities have their branches of knowledge which are still at the pre-paradigmatic level, so then history of physical culture is one. The thematic group comprising history of physical education, history of sport, of tourism and leisure, pursued professionally only by a few specialists in Poland, despite being autonomous to a certain degree, cannot be recognised as an independent scientific specialisation ${ }^{1}$ [4]. The cause of that state of affairs mainly lies in the specific character of the research carried out so far, which does not yield to falsification, as the scholars from the circles around university schools of physical education and other research and teaching institutions have not managed to establish proper methods on the basis of which that research could be continued. This, however, does not mean that all research in this thematic group is para-scientific.

It would be a good idea to quote Umberto Eco's opinion on the scientific nature: the subject matter of research is identifiable and can be defined in such a manner so that it could be identifiable to others; research has to disclose what has not been said or seen yet, research has to be useful to others, research has to provide details allowing verification or refutation of the presented thesis as well as of the material that will make it possible to be developed by future generations [5: 53-58].

\footnotetext{
${ }^{1}$ Falsification of a thesis means no more no less but verification of a counter thesis. For instance, the thesis "all the crows are black" falsified
} will end up in a positive verification of "there is at least one non-black crow". 


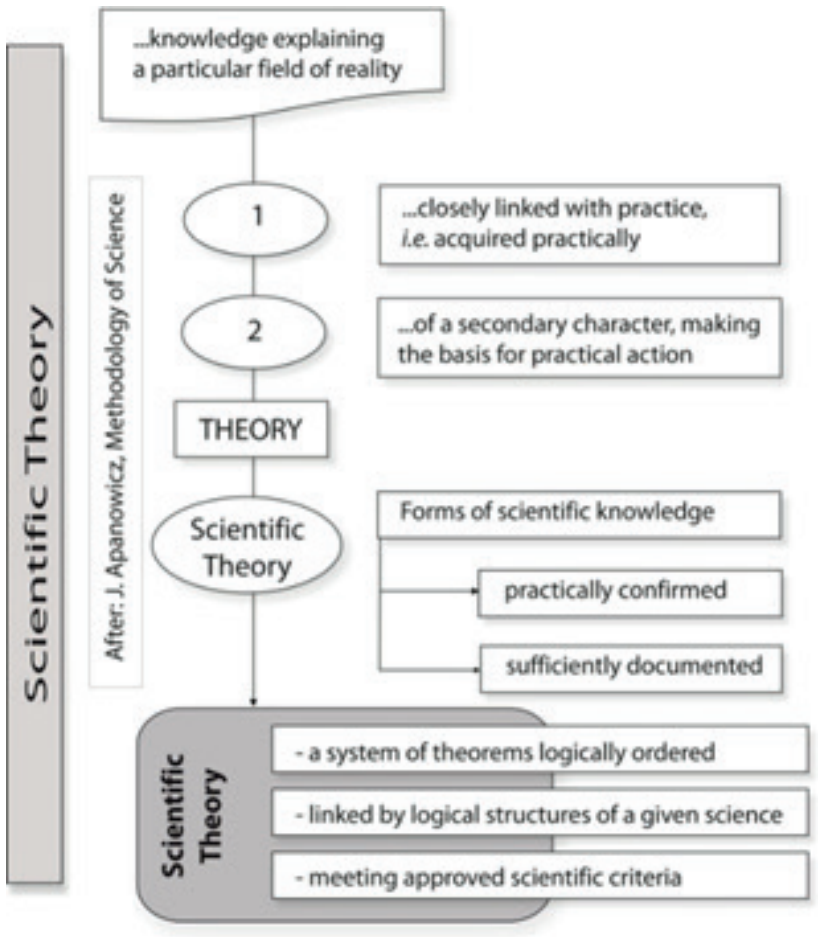

Fig. 8. Scientific theory after J. Apanowicz [6]

The contemporary standards of science are generally known. Now, it can only be pretended that history of sport, of physical education, of tourism and leisure is something unknown in the scientific perspective, not what it is commonly felt to be. It is obvious that history of sport cannot be a subjective reconstruction of the past, but its objective documentation. In order to understand a certain history, it is not enough to conduct deep and reliable research, it is also interpretation, continuous advancing of theses and challenging them, looking for the truth from more than one perspective. Therefore, the sport historian's work should not be reconstruction, recreating what used once to be.

No science can be a province of itself without its theories, neither can history of sport. If we intend to study history of science, arts, theatre, film, music, literature, medicine, it will soon turn out that no progress is possible without a theoretical paradigm. Hence a question arises of how it is possible for specific research programmes to have been pursued for more than half a century without their own theories and the paradigm ${ }^{1}$, understood here as a collection of concepts and theories composing the methodological basis. What is more, a group of researchers with considerable achievements in historiography of sport, physical education and tourism have not produced anything that could be called a methodology. Well, the case is probably more complex than it seems to be; however, at least two key causes lie at the bottom. Firstly, part of the researchers who graduated from history departments may have concluded that history of sport was a history of a specific branch, and as such, it was subject to the paradigms of the historic methodology. Secondly, there are those, including distinguished scholars in these areas, who avoid discussions on methodologies, steer of theoretical problems taking the pragmatic as a guideline. And the fact that both do not hang in the mid-air, represent various research centres and have their followers, most often disciples after their own model, makes them considerably numerous. 
It is an undisputable fact that papers on the methodology and theory in history of sport are few and far between ${ }^{1}$. Although the 1950s saw the first attempts at launching discussions on methodology, it was the dictates of historical materialism desperately sought to be applied in studies of the so-called physical culture. Even though found pilloried by the ruling ideology, servility and conformity of the then experts in history of physical culture, the mode of writing on history of physical culture failed to give in to the Soviet methodology. What remained was mere declarative statements and few papers which referred more to teaching history of physical culture. Thereafter only descriptive papers dealing with the progress of research and reports by this or another centre were published. They were not, however, papers evaluative in character or tackling issues in methodology.

The first attempts to formulate a paradigm of history of sport (physical culture) surfaced in the mid-1990s initiated by the present writer. The first was in 1995 [7: 129-133], and others followed in 1997-2007 [8-12]. The works by Z. Krawczyk, which, much as they may refer to the whole of the humanities of physical culture or express general afterthoughts on methodologies, are still meaningful, and their content is important for researchers into traditions of physical culture [13: 56-64].

Paradigms of history of sport are not identical with the paradigm that the traditional sciences of physical culture or history show, hence a need to create its own paradigm appears to be indispensable.

A broad spectrum of historical research makes sciences of sport take advantage of specific methodologies of the fundamental sciences such as biology, physiology, biochemistry, biophysics, medicine, philosophy, sociology, psychology, pedagogy, history and so forth. According to F. Breudel, "there is not a clear-cut boundary between the humanities. Each is an open gateway to the wholeness of social reality leading to all rooms and all floors of the house, providing the researcher does not stop over in his itinerary on account of his neighbours" [14: 233].

Z. Krawczyk attempting to exemplify the approaches towards history of sport, understood as part of sciences of physical culture, suggests "a historical process, moment and duration, an objective dimension and subjective reflection of historical events - these are the components that build up the historical technique of [the] mentioned researchers [13: 62]".

A scientific history of sport is a concatenation of uniform and ordered theorems which combine principles accepted by the majority. Such a system forms a theory, a methodology of history of sport, elevates research to the rank of science. Hence, working out an individual methodology should become one of the major objectives of the sport history researchers. If a sport historian assumes that history of sport can be a chronicle, just a story told about the development of sport disciplines, important events, then a history understood in this way will describe "what used to be". Moreover, when the researcher sets about describing isolated, sometimes spectacular stories related to the events or incidental facts, hoping at the same time that writing biographies of outstanding athletes, coaches or activists taking part in these events has a substantial impact on the course of the historical process, then he may expect negligible scientific effects.

\section{CONCLUSIONS}

1. A feature of thematic groups connected with history of sport, physical education and tourism isolated from the sciences of physical culture is that the majority of researchers in this area underestimate the need to create theoretical grounds for their research. How then

${ }^{1}$ Further on the paper will deal with issues in history of sport, nonetheless the content hereof will be addressed to historians of physical education, tourism, leisure, and - possibly - rehabilitation - that is a group commonly referred to as "historians of physical culture" since the dawn of historical materialism. 
can any work of an important scientific value be carried out without a preliminary search for its paradigm - theory is tantamount to the recognition of any study of history of sport as a science. The increase in the number of sport history scholars as observed recently in the younger generation of doctorate holders, or even habilitated doctors, heralds the coming of a generational change, but will this be equal to quick upgrading of the so far practiced school and a more disseminated discussion about the scientific method - a paradigm of history of sport? Will the historians of sport be as brave as to accept a principle that without postgraduate studies (in history or sociology) future $\mathrm{PhD}$ holders will not be able to cope with the complex problems in methodologies and will fail to improve the quality of scientific research?

2. A researcher of tradition of sport faces up an important dilemma in methodology, namely whether the subject of his research should be sport in an historical approach or history of sport. In the former case, he will be a representative of sciences of physical culture, in the latter he will represent one of the disciplines of history sciences. Explorers belonging in sciences of physical culture analysing sport from an historical perspective will face a harder task - they will be up to building a method, a non-existent paradigm of their studies.

3. Seen from the outside, retrospective research into sport, physical education and tourism formed just a small area within the framework of sciences about physical culture. The fruits of the work by these researchers in this thematic group (possibly due to their low originality or methodological value of a large part of the work by the first generation) did not generate much demand nor raise much interest of the scholarly circles. The course that the so-called historians of physical culture took did not hold much interest of naturalists and practitioners teaching at University Schools of Physical Education, nor did they treat them seriously. The results of the research by academics from University Schools of Physical Education pursuing that field were also neglected (with few exceptions) by university historians. Strangely enough, this state of affairs was conducive to a quick academic promotion to a doctoral degree in sciences about physical culture. However, curious as it was, whether a degree was awarded or not in this thematic group depended (and still does) solely on the naturalists, which resulted in reduced reviews, and, subsequently, a lowered scholarly quality.

4. Certainly, history of sport should not only reconstruct events, a view of the past freed from relativistic attitudes, while writing history should by no means be the researcher's reflection - records of his own knowledge about the events he is describing. Such history writing would be devoid of universal meaning, would only meet a demand of the local community and reduce the readership.

5. Looking for new methods of scientific pursuance of history of sport appears to be a topical issue especially that we must depart from combining only facts materially, chronologically and spatially in favour of explaining the essence of the historical process, of synthesising the wholeness of the relations taking place within the sphere of social events. It seems that history of sport will be drifting towards creating new thematic hybrid in, for example, sociohistory of sport, sport policy, ethnohistory, political history of sport, history of the theory of sport, history of the Olympic movement, history of philosophy of sport, history of medicine of sport, etc.

6. A retrospective insight into sport may take two forms: research into historical sport and research into history of sport. Research into historical sport is usually carried out by university history departments and focuses on issues in sport, while issues related to social processes, complex relationships between sport and politics, social and cultural processes are the objective of historical research. On the other hand, research into history of sport is conducted chiefly by research centres at university schools of physical education most often by experts in sciences of physical culture, and generally concentrate on chronicles of 
local history of a single or a couple of sport disciplines and description of their organisation, development of sport disciplines from a national perspective in historical periods, and compiled biographies. In this way, research is enclosed in thematic enclaves, while essential problems from a perspective of sciences of physical education remain hibernated.

7. Pursuing history of sport in a scientific manner, that is the so-called "history of physical culture" for a physical culture researcher is not history; it is a thematic group within the framework of these sciences. Physical culture science researchers should study sport in a retrospective manner (historical), and without inferiority complexes account for the needs of science of sport and sport teaching, leaving pure history of sport to those who look into it from a completely different branch of science - history.

8. Presently arriving at interesting results in historical research is more likely where two or more disciplines meet - hence a sociologist knowledgeable in sport, cultural anthropologist, etc. Certainly, new sub-disciplines will be emerging: historical psychology of sport and historical sociology of sport. The fact that mass sources are available makes research into recent history of sport turning into a multidisciplinary study area. An increase in the number of interdisciplinary, multidisciplinary and transdisciplinary links will evolve.

\section{REFERENCES}

[1] Grabowski H. Czy dezintegracja nauk o kulturze fizycznej jest nieuchronna? [Is the disintegration of physical culture sciences inevitable?]. Trening.1998;1:91-103. Polish.

[2] Rodniański J. O myśleniu skutecznym [About effective thinking]. Warszawa; 1964. Polish.

[3] Kosiewicz J. Nauki o kulturze fizycznej i filozofia [Physical culture sciences and philosophy]. Roczniki Naukowe AWF Warszawa. 2002; XLI:8-11. Polish.

[4] Godlewski P. O miejscu badań historii sportu w nauce [About the place of research on the history of sport in science]. In: Nowak L, editor. Z najnowszej historii kultury fizycznej w Polsce [From the recent history of physical culture in Poland] Vol. 8. Gorzów Wlkp.; 2008, 12-17. Polish.

[5] Eco U. How to write a thesis, Polish translation. Warszawa: Uniwersytet Warszawski; 2007.

[6] Apanowicz J. Metodologia nauk [Methodology of science]. Toruń; 2003. Polish.

[7] Godlewski P. Wychowanie fizyczne i sport w badaniach kultury fizycznej - rzeczywistość a potrzeby [Physical education and sport in research on physical culture - reality and needs]. Monograph No. 318. Poznań: AWF; 1995. Polish.

[8] Godlewski P. In search of ethnic elements of forms of physical culture, In: Actas del Congreso International de Luchas y Juegos Tradicionales. Madrid; 1996, 559-569.

[9] Godlewski P. Współczesne heterogeniczne oblicze sportu - refleksja terminologiczna i metodologiczna [Współczesne heterogeniczne oblicze sportu - refleksja terminologiczna i metodologiczna]. In: Rychta T, Chelmecki J, eds. Wkład nauk humanistycznych do wiedzy o kulturze fizycznej. Vol. I, Historia kultury fizycznej (studia i szkice) [Contribution of the humanities to the knowledge of physical culture. Vol. I, History of physical culture (studies and sketches)]. Warszawa; 2003, 43-48. Polish.

[10] Godlewski P. Ideological paradigm of physical culture in former communist-ruled countries in the Stalinist era. In: Teja A, Krüger A, Riordan J, eds., Sport e Culture. Committee for Sport History (CESH). Crotone Italia 26-29 settembre 2004. Band II - Etàmoderna e contemporanea. Crotone: Edizioni del Convento; 2005, 264-273;

[11] Godlewski P. Kultura fizyczna - termin i system na usługach marksistowskiej ideologii [Physical culture - term and system at the service of Marxist ideology]. In: Dziubiński Z, editor. Sport jako kulturowa rzeczywistość [Sport as a cultural reality]. Warszawa; 2005, 520-534. Polish.

[12] Godlewski P. The heterogenous nature of the history of sport. A Look from the East. In: Lämmer M, Terret T, eds. New aspects of sport history. ISHEPS-Studiem 13/7. Köln; 2007; 411-416.

[13] Krawczyk Z. Kultura fizyczna - ciągłość i zmiana [Physical culture - continuity and change]. In: Kosiewicz J, editor. Sport, kultura, społeczność [Sport, culture, community]. Warszawa; 2006.

[14] Breudel E. Historia i trwanie [History and duration]. Warszawa; 1971. Polish. 